\title{
The Effect of Site Environmental Analysis of Mass Building Orientation in Restaurant and Course of Cooking Asian Cuisine in Ubud, Bali
}

\author{
Luh Putu Devi Aprilinda ${ }^{1}$, I Wayan Kastawan ${ }^{2}$ \\ Bachelor Degree of Architecture Study Program \\ Faculty of Engineering-Udayana University \\ Jimbaran \\ deviaprilinda@gmail.com \\ Architecture Study Program \\ Faculty of Engineering-Udayana University \\ Jimbaran
}

\begin{abstract}
Restaurant and Asian Cuisine Cooking Courses are culinary and tourism which is strategically located in Ubud tourism area, Ubud district, Gianyar Regency. The principal things the development of tourist attractions in this region are the high number of domestic and international visitors. The high desires of the tourists are a fundamental consideration of the development of Restaurant and Asian Cuisine Cooking Courses with its main dishes based on Asian cuisine. With the high trade of competition in the culinary in Ubud, Restaurant and Asian Cuisine Cooking Courses in Ubud is packed uniquely by adding other facilities such as cooking classes and agro tourism. The development of the tourism area is utilized as good as possible by providing tourists with high quality facilities. The most important thing that un-derlies this design is the direction of the building orientation that is comfortable for the community who carries out ac-tivities in it. There are some activities that can be done by users, such as culinary and cooking courses. Therefore, ac-cording to its function, zoning is determined in accordance with its function in order to make it conform to the function. The site chosen in this design carried out several analyzes to determine the accurate direction of orientation.
\end{abstract}

Index Terms - Tourism, Culinary, Restaurant, Ubud

\section{INTRODUCTION}

The embodiment of Balinese buildings is indeed known synonymous with the use of natural stone material which is exposed in such a way and is not given additional coloring / coating. The material used is usually in the form of bricks and sandstone obtained from river banks in Bali. Many of these materials are applied for making ornaments on temples, houses, walls / shearers, merajan, and others. Natural stone which is very much needed for development in Bali has resulted in the use of natural stone being directly proportional to the development in Bali. The building of an artificial natural stone craftsman center in Gianyar is a centralized location of craftsmen in the Gianyar area who produce similar products and / or work on the same production process, equipped with supporting facilities and infrastructure designed to be able to develop the potential of the area. The same type of product referred to is artificial natural stone, artificial natural stone is natural stone that is processed in such a way that is capable of possessing properties such as natural stone. Natural stone has very promising potential due to the high market demand, on the other hand natural exploitation in natural 
stone producing regions will be a problem going forward. This building will every day produce a variety of artificial natural stone and environmentally friendly materials to meet market needs both in Bali and outside the region. The design of the center of artificial natural stone makers is also expected to be able to absorb labor so that the number of disruptions will be reduced. This center will open up opportunities for cooperation and research between the private sector, regions and academics. This building will be built in Gianyar around the area of Singapadu Village which is still known as a center for natural stone craftsmen.

Natural stone craftsman is one of the civitas that plays an important role in this building. Craftsmen are people whose job is to make handicraft items or people who have skills related to certain handicrafts. These goods are not made by machine, but by hand so that they are often called handicraft goods. Craftsmen are at risk of having a work accident while making crafts. The principle of occupational safety and health (K3) is an important thing that must be applied to this facility so that craftsmen feel safe, comfortable, healthy doing their work so that the quality and quantity of production is optimal.

\section{RESUlt AND ANALISYS}

\section{A. Purpose, Civity and Functions}

Culinary is one of the main objectives of tourists when visiting an area is the diversity of food available, both domestic food and food style of terror. there are times when people visit a place to hunt for food or snacks as well as for a vacation to make this tour a culinary tourism business that is quite promising. For the literal meaning of travel is to travel together to expand knowledge, wawa-san, etc[1]. Whereas Culinary means food or food and, cooking class is one of the facilities for tourists who are served by this culinary tour. So, in addition to eating delicious food in the restaurant, tourists can also cook directly the food to be served in a simple cooking class.

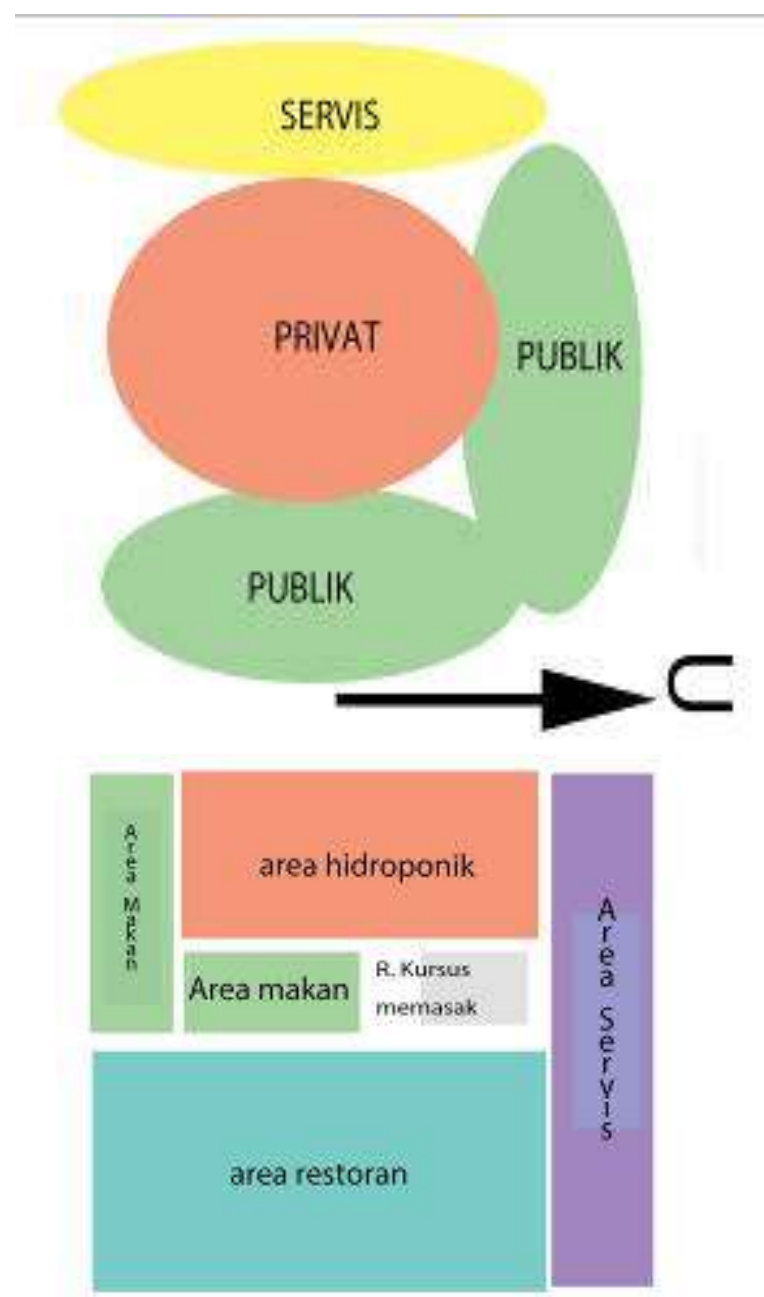

Fig. 1. Zoning and Mass Building Restaurants and Cooking Courses for Asian Cuisine in Ubud

Building orientation is in the form of building orientation based on the superior view at the location, and facade processing based on responses from the surrounding environment that has been formed. Flat topographical conditions are not contoured. The building has 2 facades on the front and back, one face of the building faces in the direction entrance to the site, and one face of the building facing the midpoint of the site which becomes the site's viewpoint. The restaurant faces north and south leading inwards, towards the built scenery. Noise caused by motorized vehicles is minimized for the cooking course area and visitor dining area. The building orientation is directed towards the superior views giving a view to the building, also giving a view of the lina-kunaan kunai around the baaunan. a. The orientation of the building is more directed at: The atmosphere from the direction of the site view of the built site footprint made in the form of farming and hydroponic areas. Buildings give a view to the environment through: Ringroad (traffic density) atmosphere in Ubud (density of visitors) Buildings are given special treatment in areas that receive more attention from the environment as a building attraction (giving a 
view to the surrounding environment). Public space groups are placed at the front of the building, because it is public by visitors. The service room is located next to the building to the west or is closed and has its own access so that visitors are not reachable.

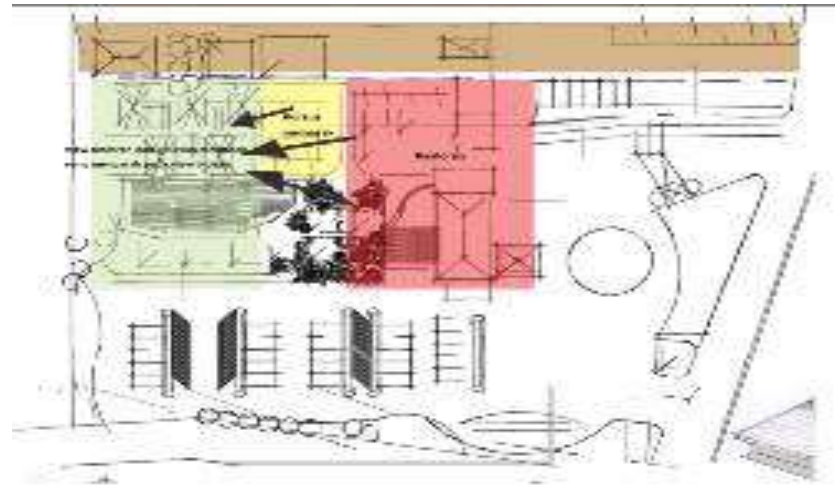

Fig. 2. Location of the Patronage of Restaurants and Cooking Courses for Asian Cuisine in Ubud

Site has three zoning, namely public zoning, semiprivate zoning, and private zoning. Public zoning on the site is zoning that is traversed by all civitas who are active in it, while semi-private zoning is zoning which can only be traversed by a few civitas, and private zoning is only yes specifically designated. The division of zoning is based on the needs of each civitas. So that, through zoning, mass patterns can be formed from the building. Building orientation must be in accordance with other factors, in order to get the most benefit from natural heating and cooling techniques. According to Setyo Soetiadji [1] orientation is "a relative position of a form to the basic plane, the direction of the compass, or the view of someone who sees it. By orienting and then adapting local situations and conditions, our buildings will become the property of the environment. In this Restaurant and Cooking Course for Asian Cuisine in Ubud, it has a point of view which can be seen from all directions of each building period contained in it. At the point of the view that is in the middle of the site is made in such a way as to blend with the surrounding natural environment so that, it looks soothing and does not cause heat, besides that the view can be enjoyed from all positions, the selection of appropriate orientation and processing of the shape of the building in the area. lamnya it will present an interesting view.
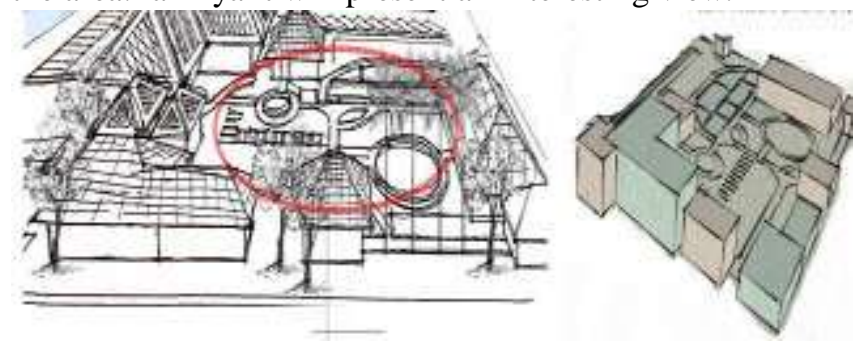

Fig. 2. Regional Perspectives and Zoning

\section{B. Site Analysis}

The concept of this project is, as a new tourist destination with an educational concept of tourism in addition to presenting only culinary tourism, besides accommodating the interest of tourists to the taste of Asian cuisine with cooking courses 2 and the introduction of some of the results of farming provided by the pasting system can cook the harvest yourself. Restaurants \& Cooking Courses The Asian Age in Ubud is to preserve the empowerment of local plants, especially local vegetation to avoid the import system, and provide Asian culinary tourism and improve the economy of surrounding communities through the tourism sector. While the target of the Restaurant \& Cooking Course for Asian Cuisine in Ubud is all levels of the Ubud Village community who work directly in their field of work, and tourists visiting Ubud to enjoy the Ubud Village.

\section{Location}

Location of Restaurant and Cooking Course for Asian Cuisine in Ubud is located in Ubud District, Gianyar Regency. This site has an area of $26 \mathrm{~m} 2$. The shape of the whole building adapts to the available tread shape, which tends to be trapezoidal. Located on the main road, Jalan Raya Ubud, heading south is Bisma Street on the west side. Jl. Bisma is the road to this Asian Cuisine Restaurant and Cooking Course in Ubud. in the area around the site there is a vast expanse of rice fields with a surrounding environment in the form of villas, restaurants, and other tourist attractions. Although the Restaurant \& Cooking Course for Asian Cuisine in Ubud is not located on the protocol road in Ubud, it will be built as attractive as possible with its uniqueness and can bring domestic and foreign tourists. Meanwhile, with congested and not so large roads, food will be built in special parking lots that are sufficient to avoid parking on the side of the highway which causes traffic jams.

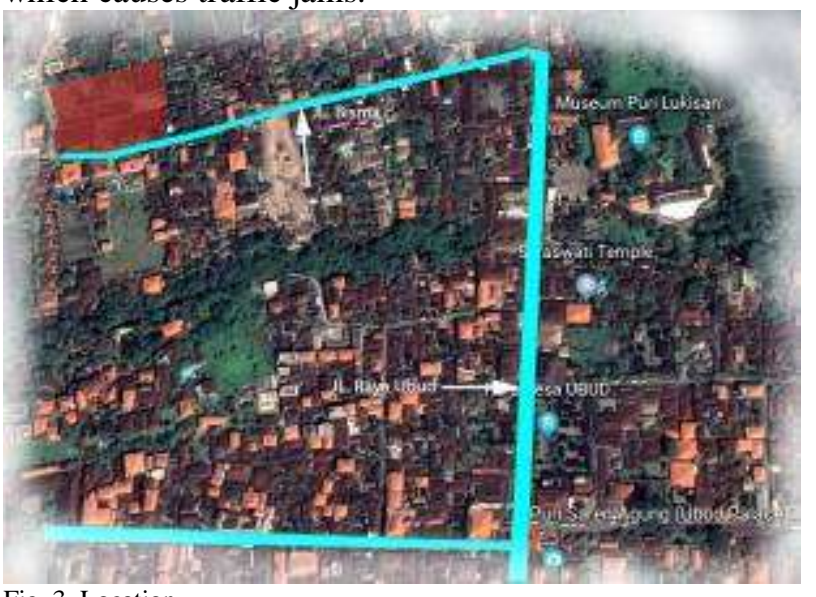

Fig. 3. Location

\section{Environment Analysis}

Based on the existing data about the noise outside the site, several analyzes are obtained, namely in the North which is the location of the main entrance which is a 
public area which has the highest level of noise, while reentering the site to the west is a semi-private area with moderate noise level and the most western and southern regions are the most private areas because they have the lowest noise levels. The north is a typical Balinese shop / souvenir, and there are several small eateries. This is a positive sight as well as facilitating the tourists. The south direction is paddy fields, this is a positive view that makes the site attractive, East and west directions are villas / lodging areas. the building mass orientation is facing the positive view to the north because it is the main road to the site and also makes openings to the building mass in all directions so that positive views from the north, east, south and west can be drawn into the site while paying attention to the local climate. Meanwhile, for inward views, the appearance of the building will be made as attractive as possible with an attractive landscape arrangement so that the civitas who are active in the building and around the site. As a result of the influence of orientation on something, causing the building must be able to anticipate negative things related to the problem of building physics including thermal problems, rainwater tampias, glare and so forth. The sun reflects disturbances from heat and glare (Wijaya, 1988). Protection that can be done to anticipate the problem can be used several ways, as for ways that can be done among others by the principles of shading and filtering / filtering light.

\section{E. Concept}

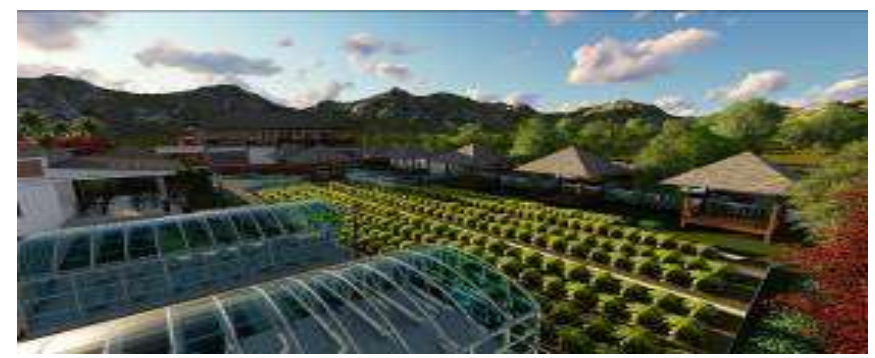

Fig. 4. Perspective

The picture above is a hydroponic area and a growing area that is used as a scenic spot that sells from restaurants \& cooking courses for Asian cuisine in Ubud. The location does not have a natural view that makes this place attractive to visitors, so the planners have made a hydroponic area with a large area of cultivation as an open area that can be enjoyed by visitors. The locations on the site that are preferred for scenery are: restaurants with outdoor dining areas located around the hydroponic area, and cooking course areas. Visitors can also explore the surrounding area. So that the entire orientation of the building has 2 faces, one of which faces toward the midpoint of the building zoning point. Besides the impact on the circulation of visitors is more directed at each destination, circulation is chosen using a radial circulation pattern. Radial circulation pattern is a circulation pattern that has a point that becomes the center. This radial circulation pattern has a road pattern that develops into several branches or menus of a place. The application of this radial circulation pattern can be seen in the placement of building mass patterns. The cooking course area and restaurant are the main functions in the site, but are designed in different masses of buildings because they do not have a relationship to one another. In this restaurant \& cooking course in Asian cuisine, the restaurant is devoted only to visitors who want to enjoy culinary tourism, but if you want to take a cooking course you can enjoy dining in a different way, namely in the dining area that has been prepared, so from that the cooking course area and restaurant area are designed at different times of the building. Meanwhile, in the area of farming and hydroponics is a complementary function, it can be a very educational tour.

\section{CONCLUSION}

Based on the explanation from the illustration above, the conclusion is drawn that the Restaurant Design and Cooking Course Asian Cuisine in Ubud is designed to require a view especially in the main building, namely: Restaurant, Cooking Class Room which is enjoyed by tourists. The direction of orientation affects the pattern of the building period and the spatial relationship of each building period, so that in space programming it should be considered properly and correctly so that a harmonious relationship is created in the interrelation of the building period on the site.

\section{REFERENCES}

[1] Suparwoko., "Culinary: pemahamannya terhadap kuliner", 2010. 